\title{
EUROPEANIZATION: SIMPLY A TOP-DOWN PROCESS?
}

\section{Nguyen Thi Thuy HANG*}

\section{Abstract}

There have been intense, wide-ranging, and confused debates about what Europeanization is in the field of European studies. Many interpret Europeanization from a 'top-down' perspective with an emphasis on the unidirectional impacts of European integration on member states. However, it is argued in this article this 'top-down' logic ignores the two-way interaction between domestic and EU level, and how European politics, policies and polities can be shaped by the domestic level. It is argued that Europeanization should not be understood solely as the effects of EU level on member states. It shows that the nature of Europeanization can be best captured with the combination of three approaches: downloading, uploading and crossloading. Hence, the article recommends an incorporated approach and its model that has the potential to provide a full understanding of what Europeanization is.

Keywords: Europeanization, downloading, uploading, crossloading, topdown, bottom-up, European studies.

\section{$\ddot{O}_{z e t}$}

Avrupa çalışmaları alanında Avrupalılaşma hakkında geniş kapsamlı, yoğun ve karışık tartışmalar yaşanmıştır. Birçokları Avrupalılaşma'yı, Avrupa entegrasyonun üye devletler üzerindeki tek yönlü etkilerine vurgu yaparak 'yukarıdan-aşağıya' perspektifinden yorumluyor. Ancak bu makalede, bu 'yukarıdan aşağıya' mantı̆̆ının, ulusal ve AB düzeyindeki iki yönlü bir etkileşimi ve Avrupa siyaseti, politikaları ve yönetiminin nasil

M.A. candidate, University of Sheffield, International Studies, e-mail:

HTTNguyen1@sheffield.ac.uk 
ulusal düzeyce şekillenebileceğini yok saydı̆̆ ileri sürülmektedir. Avrupalılaşma sadece üye devletlere AB düzeyinde etkiler olarak anlaşılmamalıdır. Avrupalılaşma'nın doğası, üç yaklaşımın bir kombinasyonu olarak en iyi şekilde anlaşılabilir: indirme, yükleme ve çapraz yükleme. Bu nedenle makale, Avrupalılaşma'nın ne olduğunun net olarak anlaşılmasını sağlamak için bir potansiyel sunan birleştirilmiş bir yaklaşım ve onun modelini önermektedir.

Anahtar Kelimeler: Avrupalılaşma, indirme, yükleme, çapraz yükleme, yukarıdan aşağıya, aşă̆ıdan yukarıya, Avrupa çalışmaları.

\section{Introduction}

Europeanization has become a prominent but disputed term in the field of European studies. Some consider Europeanization as a top-down process in which attention is exclusively paid to the influence of the EU on the political institutions, policies and political forces of the member states. Others argue that it is necessary to view it from both bottom-up and horizontal approaches. Recent studies have shown that an attempt to bring the three perspectives together will lead to a more comprehensive understanding of Europeanization. With this in mind, the article begins by giving an overview of the top-down process whereby member states download or receive new sets of norms, rules and policies from the $\mathrm{EU}^{1}$ before arguing that this approach is important but insufficient to capture the nature of Europeanization. Then, the article argues that two more approaches, bottom-up and horizontal, should also be employed to best understand Europeanization. From the bottom-up approach, Europeanization is an uploading process in which member states export or project their preferences to the EU level. ${ }^{2}$ The ability of member states to

${ }^{1}$ K. H. Goetz and J. H. Meyer-Sahling (2008) 'The Europeanisation of National Political Systems: Parliaments and Executives', Living Reviews in European Governance 3:2, http://www.livingreviews.org/lreg-2008-2 (accessed 7 March 2011).

2 S. James (2007) 'Europeanisation as 'Projection': Understanding the Changing Face of EU Policy Making within the Core Executive European Policy Research Unit (EPRU)', Political Perspectives EPRU 2007, 2: 3, http://www.politicalperspectives.org.uk/wp-content/uploads/2010/08/EPRU-2007S1-03.pdf (accessed 7 March 2011). 
influence EU policies and the decision-making processes in the EU institutions demonstrates that member states are not passive in the process of European integration. From horizontal approach, Europeanization is a 'crossloading' process which refers to the exchange of ideas, power, policies and values between member states. ${ }^{3}$ Furthermore, the article suggests that an incorporated approach and its model have the potential to provide a full understanding of what Europeanization is. In conclusion, the article highlights the added value of a refined Europeanization concept. Assertively, no single approach to Europeanization should be expected to cover all complex dynamics of European integration. The three approaches, top-down, bottom-up and horizontal, interact to bring about domestic transformation. Thus, considering Europeanization from such an incorporated approach is desperately needed to fully capture its nature.

\section{Europeanization from Top-down Approach: Incomprehensive Picture}

An

'Europeanization' is a "fashionable" ${ }^{4}$ and 'hotly contested" term in the field of European studies. In its broadest meaning, Europeanization can be understood as 'becoming more European like.' More specifically, many scholars have defined Europeanization as a top-down process characterised by an emphasis on the influence of European integration on member states level. ${ }^{6}$

\footnotetext{
${ }^{3}$ C. Major and K. Pomorska (2005) 'Europeanisation: Framework or Fashion?', CFSP Forum, 3:2, p.1,

http://unimaas.academia.edu/KarolinaPomorska/Papers/110624/Europeanisation fr amework or fashion (accessed 11 March 2011).

${ }^{4}$ J. P. Olsen (2002) 'The Many Faces of Europeanization', Journal of Common Market Studies, 40:5, p. 921.

${ }^{5}$ I. Bache (2008) Europeanization and Multilevel Governance: Cohesion Policy in the European Union and Britain, Plymouth: Rowman and Littlefield, p.9.

${ }^{6}$ J. Buller and A. Gamble (2002) 'Conceptualizing Europeanization', Public Policy and Administration-Special Issue Understanding the Europeanization of Public Policy, 17: 2 pp. 4-24; K. Dyson and K. Goetz (2002), Germany and Europe: Beyond Congruence, a paper presented at Germany and Europe: A Europeanised Germany? Conference British Academy; S. George, (2001) The Europeanization of UK Politics and Policy-Making: The Effects of European Integration on the UK. UACES/ESRC Workshop Sheffield University.
} 
One of the earliest definitions of Europeanization is put forth by Ladrech (1994): Europeanization is simply seen as 'an incremental process of reorienting the direction and shape of politics to the extent that EC political and economic dynamics become part of the organizational logic of national politics and policy making., ${ }^{7}$ This conceptualization is based on the 'topdown approach' to Europeanization with change emanating from the influence of the EU onto the domestic policy. In other words, Europeanization generates changes in domestic policies and institutions as adaptive response to European challenges. In a similar vein, Radaelli (2004) describes Europeanization as 'processes of a) construction, b) diffusion and c) institutionalisation of formal and informal rules, procedures, policy paradigms, styles, 'ways of doing things' and shared beliefs and norms which are first defined and consolidated in the EU policy process and then incorporated in the logic of domestic (national and subnational) discourse, political structures and public policies. ${ }^{8}$ Despite Radaelli's acknowledgement of the existence of different Europeanization dynamics, he focuses largely on the transformative effect of the EU governance system on the political institutions, policies, and political processes of the member states. Thus, national policy areas become increasingly dependent on European policy making.

The top-down approach has made an important contribution to identifying and explaining the causal mechanisms through which EU-level processes lead to domestic change. From this view some 'misfit' or 'mismatch'10 does exit between European and domestic policies, processes and institutions. It creates some adaptational pressure between the EU and its member states. Bache and Jordan (2006) underscore that without such

${ }^{7}$ R. Ladrech (1994) 'Europeanization of Domestic Politics and Institutions: The Case of France', Journal of Common Market Studies, 32:1, p.69.

8 C. M. Radaelli, (2004), 'Europeanisation: Solution or Problem?', European Integration online Papers (EIoP), 8:16, available: http://eiop.or.at/eiop/texte/2004016a.htm (accessed 5 March 2009).

${ }^{9}$ F. G. Dunia (1999) Harmonizing Europe: Nation-states within the Common Market, New York: State University of New York Press.

${ }^{10}$ A. Héritier (1996) 'The Accommodation of Diversity in European PolicyMaking' Journal of European Public Policy, 3:2. 
adaptational pressure, 'Europeanization cannot logically occur.,"11 Furthermore, the 'goodness of fit' between European and domestic level is a determinant of the degree of pressure for adaptation generated by Europeanization on the member states: 'The lower the compatibility between European and domestic processes, policies, and institutions, the higher the adaptational pressure.' ${ }^{12}$ Specifically, if European policies, politics and institutions are compatible with those at the national level, member states do not need to alter their legal provisions. For instance, to join EMU member states were required to make their national central banks independent. Therefore, the French government had to revise the relevant national legislation to make Banque de France, a central bank traditionally dependent on the French government, become independent. On the contrary, the German central bank, the Bundesbank, had enjoyed independence from the Federal government from its inception. Thus, it did not have to experience great changes. ${ }^{13}$

Although it plays a significant role in explaining domestic change, 'topdown' approach is not without its critics. Börzel (2005) observes that the 'top-down' approach ignores the two-way interaction between the national and EU levels, and how member states can shape European policies. From 'top-down' approach, it is implied that member states are 'passive receivers of European demands for domestic change.' ${ }^{14}$ It is argued that viewing Europeanization merely as 'the penetration of the European dimension into the national arena' ${ }^{15}$ as the top-down approach guides will lead to a biased knowledge of the relationship between the EU and member states. The top-

${ }^{11}$ I. Bache and A. Jordan (2006) The Europeanization of British Politics, (eds.), Basingstoke: Palgrave Macmillan, p.23.

${ }^{12}$ T.A. Börzel and T. Risse (2003) 'Conceptualizing the Domestic Impact of Europe' in K. Featherstone and C. Radaelli (eds) The Politics of Europeanization, Oxford: Oxford University Press, p.61.

${ }^{13}$ L. Quaglia et al (2007) 'Europeanisation' in M. Cini (2 ${ }^{\text {nd }}$ edn.) European Union Politics, Oxford: Oxford University Press, p.409.

${ }^{14}$ T. A. Börze (2005) 'Europeanization: How the European Union Interacts with its Member States' in S. Bulmer, and C. Lequesne (eds) The Member States of the European Union, Oxford: Oxford University Press, p.62.

${ }^{15}$ A. Gamble (2001) Europeanisation: A Political Economy Perspective, the Europeanization of British public and social policies, PAC/JUC residential school, York. 
down approach tends to generate the understanding of Europeanization as a one-way arrow of interaction that is likely to oversimplify the content of Europeanization.

As a result, the argument for Europeanization as a 'mutual constitutive' process of change has been emerging. George (2001) asserts that 'member states are not passive recipients of pressures from the EU; they also try to project national policy preferences upwards. ${ }^{16}$ Therefore, Europeanization should be viewed as a two-way relationship between agency and structure in which agency is transformed by participating in the EU structure, but simultaneously agency is transforming the EU processes and structure. ${ }^{17}$ In a similar fashion, Dyson and Goetz (2003) argue that 'Europeanization denotes a complex interactive 'top-down' and 'bottom-up' process in which domestic polities, politics and public policies are shaped by European integration and in which domestic actors use European integration to shape the domestic arena. ${ }^{18}$ Such a perspective triggers a growing interest in examining other dimension of Europeanization such as the analysis of the 'national inputs' of member estates and their impact on EU policies and decision-making processes in the EU institutions (uploading process). ${ }^{19}$

More and more empirical research has revealed that the complex interactive dynamic of the EU and member states is the feature of

${ }^{16}$ S. George (2001) 'The Europeanization of UK Politics and Policy-Making: the Effect of European Integration in the UK', Queen's Papers on Europeanisation, No 8/2001, Belfast: Queen's University Belfast: http://www.qub.ac.uk/pais/Research/PapersSeries/, (accessed 25 February 2011). ${ }^{17}$ T.A. Börzel (2003) 'Shaping and Taking EU Policies: Member States Responses to Europeanization', Queen's Papers on Europeanization, No. 2, http://www.qub.ac.uk/schools/SchoolofPoliticsInternationalStudiesandPhilosophy/F ileStore/EuropeanisationFiles/Filetoupload,38412,en.pdf (accessed 12 February 2011).

${ }^{18}$ K. Dyson and K.H. Goetz (2003) 'Living with Europe: Power, Constraint, and Contestation', in K. Dyson and K. H. Goetz (eds.) Germany, Europe and the Politics of Constraints, Oxford: Oxford University Press, p.14.

${ }^{19}$ See, for example, A. Milward (1992) The European Rescue of the Nation-State, University of California Press; H. Wallace (2005) 'Exercising Power and Influence in the EU: the Roles of Member States' in S. Bulmer and Ch. Lequesne, The Member States of the European Union, Oxford: Oxford University Press. 
Europeanization, ${ }^{20}$ thus in trying to comprehend Europeanization, it is necessary to touch upon the operation of two-way pressures: uploading to the EU-level by domestic actors and downloading from the EU-level to domestic arena. ${ }^{21}$ This means that the bottom-up approach is essential to better the understanding of the relationship between the EU and member states.

\section{Europeanization from Bottom-up Approach}

The bottom-up approach to Europeanization describes how member states 'upload' or 'shape' policies, politics and institutions of the European Union. To become a successful shaper or uploader, a member state needs to 'make its preferences heard, so that an EU policy, political process or institution reflects its interests.' 22 According to Bache (2008), being aware of the logic between the EU-level requirements and domestic arrangements: poor fit creates strong adaptational pressure on the member state, good fit creates weak pressure, member states do not simply passively 'download' policies from the EU but also 'upload' their preferences to the EU level. ${ }^{23}$ This is echoed by Börzel (2005):'An effective strategy of maximizing the benefits and minimizing the costs of European policies is to 'upload' or

${ }^{20}$ T. A. Börzel (2002) 'Member State Responses to Europeanization', Journal of Common Market Studies,40:2; S. Bulmer and M. Burch (2001) 'The Europeanization of Central Government: the UK and Germany in Historical Institutionalist Perspective' in G. Schneider and M. Aspinwall (eds.) The Rules of Integration: Institutional Approaches to the Study of Europe, Manchester: Manchester University Press; K. Featherstone, and G. Kazamias (eds) (2001) Europeanization and the Southern Periphery, London: Frank Cass; S. Saurugger (2005) 'Europeanization as a Methodological Challenge: The Case of Interest Groups', Journal of Comparative Policy Analysis, 7:4.

${ }^{21}$ I. Bache and A. Marshall (2004) 'Europeanisation and Domestic Change: A Governance Approach to Institutional Adaptation in Britain', Queen's Papers on Europeanisation, p.3.

${ }^{22}$ T. A. Börzel and D. Panke (2010) 'Europeanization', in M. Cini and N. P. S. Borrogán ( $3^{\text {rd }}$ edn.) European Union Politics, Oxford: Oxford University Press, p. 412.

${ }^{23}$ I. Bache (2008) Europeanization and Multilevel Governance: Cohesion Policy in the European Union and Britain, Rowman and Littlefield, p.10. 
export national policies to the European level. ${ }^{24}$ By uploading of their policy preferences, such member states are able to evade any adjustments or modification in specific policy sector. This ultimately leads to the decrease in the costs of policy accommodation.

Significantly, Börzel (2002) has contributed to the bottom-up approach when providing a thorough analysis on the three types of national uploading strategies: pace-setting, foot- dragging, and fence-sitting. ${ }^{25}$ Pace-setting means that 'domestic policies are exported to the European level and subsequently adopted by other Member States. ${ }^{26}$ Thus, pace- setting is reserved for countries with high economic development especially in the area of regulatory policies. ${ }^{27}$ For instance, Germany with a stable monetary system, strong economy, and highly central financial institution was able to shape some of the Maastricht criteria according to its preferences. Thus it was seen as the pace-setter in the monetary convergence process. ${ }^{28}$ An additional example is the case of Britain. This member state is aware of the huge costs that European environmental policy is likely to impose. The UK's Department of Environment sought to play a more proactive role at both national and European levels as Börzel's observation: 'The Environmental Protection Act of 1990 not only brought the UK into compliance with European legislation of the 1980s but put it into the position of setting the pace in several areas of European environmental

${ }^{24}$ T. A. Börzel (2005) 'Europeanization: How the European Union Interacts with its Member States' in S. Bulmer, and C. Lequesne (eds) The Member States of the European Union, Oxford: Oxford University Press, p.63.

${ }^{25}$ T. A. Börzel (2002) 'Pace Setting, Food Dragging, and Fence Sitting: Member States Responses to Europeanization', Journal of Common Market Studies, 32:1, p. 194.

${ }^{26}$ Ibid., p. 179.

${ }^{27}$ See, for example, E. Gross (2009) The Europeanization of National Foreign Policy: Continuity and Change in European Crisis Management, Basingstoke: Palgrave Macmillan; A. Miskimmon (2007) Germany and EU Foreign Policy: Between Europeanization and National Adaptation, Basingstoke: Palgrave Macmillan.

${ }^{28}$ M. Zatezalo (2007) 'The Dual Nature of Europeanization: Divergent National Mechanisms to Common Monetary and Securities Markets Policy', http://essay.utwente.nl/58085/1/scriptie_Zatazalo.pdf. 
policy. ${ }^{29}$ Successful applications of pace-setting strategy will lead to less costly national adjustment mechanisms to EU challenges, preferably accommodation or retrenchment. By contrast, foot-dragging strategy, understood as 'blocking or delaying costly policies', seeks to stop or at least reduce the attempts of some member states to upload their preferred policy models to the European level. ${ }^{30}$ Because several member states have low level of compliance with the EU rules, they suffer bigger misfit and have to pay more for the EU policy implementation. Therefore, they hope to prevent uploading or obtain at least some compensation for implementation costs; the latter leads to transformation. According to Börzel, the most neutral strategy is fence-sitting which aims neither at exporting preferred policies to the European level nor at preventing the others from doing so. ${ }^{31}$ Those following fence-sitting strategy normally work with either 'pace-setters' or 'foot-draggers' in exchange for their support on other issue areas.

Thus, these top-down and bottom-up processes are interlinked or mutually interdependent. Understanding Europeanization merely as a topdown process - the impacts that EU-level institutions, policies and policymaking have on institutions, policies, policy-making and politics at the national level of governance is an overly narrow usage of the term. The bottom-up approach has contributed to providing deeper knowledge of Europeanization.

\section{Europeanization from Horizontal Approach}

An attempt to bring the two approaches, top-down and bottom-up together produces a better comprehension of Europeanization; however, to best understand Europeanization the horizontal approach should also be taken into account in any exploration of changes taking place in the contemporary politics, economy and society of Europe. Lenschow (2006) summarises that Europeanization refers not only to the top-down and bottom-up processes but it is also viewed as 'a horizontal process. ${ }^{, 32}$ The horizontal approach views Europeanization as 'the horizontal transfer of

${ }^{29}$ T. A. Börzel (2002) 'Pace Setting, Food Dragging, and Fence Sitting,' 32:1, p. 201.

${ }^{30}$ Ibid., p. 203.

${ }^{31}$ Ibid., p. 206.

${ }^{32}$ A. Lenschow (2006) 'Europeanisation of Public Policy' in J. Richardson $\left(3^{\text {rd }}\right.$ edn.) European Union: Power and Policy-making, NY, Routledge, p.57. 
concepts and policies between states and the EU. ${ }^{33}$ Radaelli (2004) holds that these transfers are the result of sharing ideas, power and policies between member states' actors in the context provided by the EU. ${ }^{34}$

From the horizontal approach to Europeanization, the EU creates an arena for inter-state communication and/or competition. ${ }^{35}$ Additionally, the EU provides an arena for cooperation which is characterised by the harmonization of ideas and policies between the member states. Such horizontal transfers may place pressure on national actors without the direct involvement of supranational institutions. Bulmer and Radaelli (2004) point out that the horizontal process is especially seen in the area of the Common Foreign and Security Policy, where the supranational institutions exert less influence on the member states and there is the prevalence of mutual cooperation and learning between the member states. ${ }^{36}$ Moreover, Burch and Gomez $(2003)^{37}$ and Howell $(2003)^{38}$ argue that Europeanization as a crossloading process through which member states exchange ideas and practices is not dependent on the EU. Yet, the EU can be the facilitator of such horizontal processes. To illustrate, the EU institutions, particularly the extensive committee structure, get national policy-makers and leaders into contact with each other. ${ }^{39}$ The EU also establishes formal policies aiming at

${ }^{33}$ I. Bache and A. Jordan (2006) Europeanization and Domestic Change in I. Bache and A. Jordan, The Europeanization of British Politics, NY, Palgrave Macmillan, p.22.

34 C. M. Radaelli (2004) 'Europeanisation: Solution or Problem?', European Integration online Papers (EIoP), 8:16, http://eiop.or.at/eiop/texte/2004-016a.htm (accessed 5 March 2009).

35 A. Jordan et al (2003) Policy Innovation or 'Muddling Through'? 'New' Environmental Policy Instruments in the United Kingdom', Environmental Politics, 12:1, 179-198.

${ }^{36}$ S. Bulmer and C. Radaelli (2004) 'The Europeanization of National Policy?' Queen's Papers on Europeanisation No. 1.

${ }^{37}$ M. Burch and R. Gomez (2003) 'Europeanization and the English Regions', ESRC/UACES Series of Seminars on EBP, University of Sheffield, Department of Politics, Sheffield, UK: http://aei.pitt.edu/1725/ (accessed 26 February 2011).

${ }^{38}$ K. Howell (2003) 'The Europeanization of British Financial Services', ESRC/UACES Series of Seminars on EBP, University of Sheffield, Department of Politics, Sheffield, UK: http://aei.pitt.edu/1721/, (accessed 11 March 2011).

${ }^{39}$ A. Lenschow (2006) 'Europeanisation of Public Policy,' p. 58. 
facilitating such horizontal transfers and learning processes. For example, the Open Method for Coordination is a device for transferring 'best practice models', especially in policy-areas where the EU is unable to exert topdown pressures. ${ }^{40}$

Noticeably, horizontal dynamics of Europeanization demonstrate that states can export their preferences via 'uploading' them to the EU and then have them 'downloaded' elsewhere. Evidence of such horizontal Europeanization can be seen in the changes driven by rich and strong member states to impose their own values and methods on poorer and weaker member states to serve their own interests. ${ }^{41}$ For example, Germany and the Netherlands as wealthy member states have necessary resources to export their strict environmental regulations to the EU level while less wealthy member states, namely Hungary and the Czech Republic cannot due to their lack of both resources and policies to 'upload. '42 Consequently, Germany and the Netherlands succeed in uploading their preferred environment policies to the EU which is subsequently imposed on Hungary and the Czech Republic via 'top-down' Europeanization. Therefore, Andonova (2005) concludes: 'Not surprisingly, the alignment with the EU environmental acquis is typically presented as a bitter pill that candidates have to swallow to advance their broader strategic objective of EU membership. ${ }^{43}$ This conclusion vividly illustrates how the process of horizontal Europeanization may take place.

\section{A Synthesis: Towards an Incorporated Approach}

The dynamics of European integration is so complicated that no single approach is able to provide a foundation for analyzing all domestic changes. Hence, an incorporated approach is required to justify such changes. This approach which puts forward important refinements for the

\footnotetext{
${ }^{40}$ Ibid., p. 58.

${ }^{41}$ F. Schimmelfennig and U. Sedelmeier (2005) 'Introduction: Conceptualizing the Europeanization of Central and Eastern Europe' in F. Schimmelfennig and U. Sedelmeier (eds) The Europeanization of Central and Eastern Europe, NY: Cornell University Press.

${ }^{42}$ T. A. Börzel (2002) 'Pace Setting, Food Dragging, and Fence Sitting,' pp. 196197.

${ }^{43}$ L. B. Andonova (2005) 'The Europeanization of Environmental Policy in Central and Eastern Europe' in F. Schimmelfennig and U. Sedelmeier (2005), p.135.
} 
conceptualization of Europeanization is established on an incorporation of top-down, bottom-up and horizontal processes: Europeanization is to be viewed as a three-faceted process through which uploading, downloading, and cross-loading play an equal role to explain significant changes in the EU's politics, society and economy. In other words, Europeanization can be seen as a set of processes of downloading, uploading and cross-loading. Based on this approach, a model is put forward to provide a useful framework for further research.

Figure 1. Europeanization from an Incorporated Approach

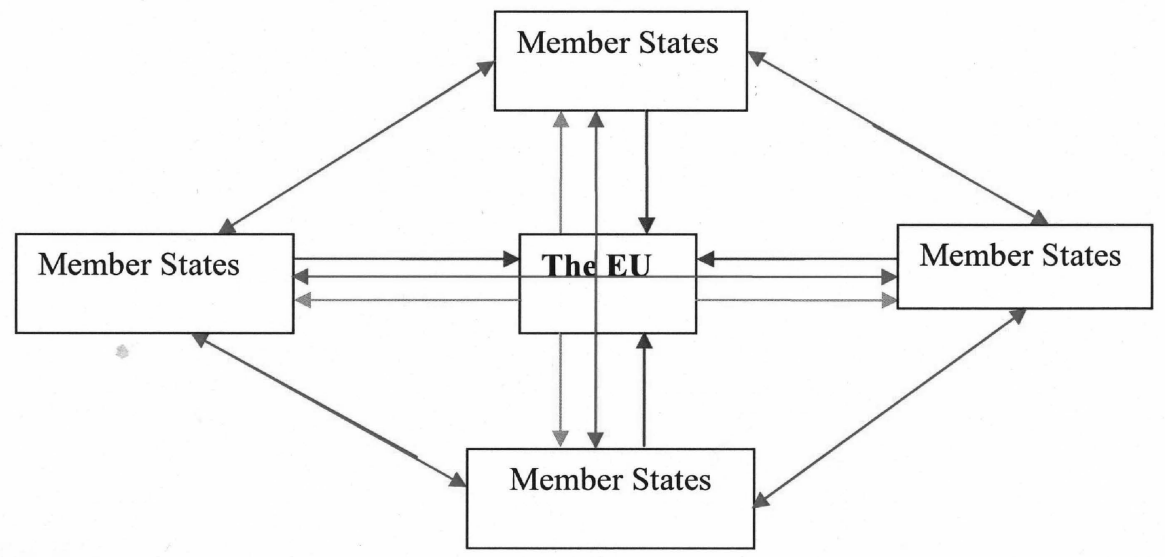

Europeanization: An incorporation of top-down, bottom-up and horizontal processes Notes:

\begin{tabular}{|l|l|}
$\stackrel{ }{\longrightarrow}$ & Crossloading process \\
\hline & Downloading process \\
\hline & Uploading process \\
\hline
\end{tabular}

Source: Elaborated by the author

\section{Conclusion}

Europeanization has emerged as a prominent branch within the study of European integration since the mid-1990s. There has been considerable literature on attempts to conceptualize Europeanization. Substantial research has concentrated on direct or indirect EU influence on the domestic policy, politics, and polity. However, this understanding of Europeanization as a top-down process is criticised for its oversimplicity. Graziano and Vink 
(2007) reveal 'there is nothing necessarily top-down about focusing on domestic adaptation to European regional integration. ${ }^{44}$ Member states as rational actors ${ }^{45}$ in the international system have sought to upload their preferred policies to the European level to reduce the degree of incompatibility. This bottom-up approach to Europeanization reflects that the relationship between the EU and member states is an interactive or twoway process. In addition to top-down and bottom-up approaches, horizontal approach concerning the inter-state transfer of concepts and policies helps to bring about the most comprehensive picture of Europeanization. Therefore, the incorporated approach with an inclusion of three processes: downloading, uploading and crossloading has the potential to provide an accurate description of the dynamics between European integration and domestic change and can be used as the analytical framework for future research on Europeanization.

${ }^{44}$ M. Vink and P. Graziano (2007) 'Challenges of a New Research Agenda' in P. Graziano, and M. Vink (eds) Europeanization: New Research Agendas, Basingstoke: Palgrave Macmillan, p. 8.

${ }^{45}$ K. Waltz (1979), Theory of International Politics, McGraw Hill. 


\section{References:}

\section{Books}

Bache, I. (2008) Europeanization and Multilevel Governance: Cohesion Policy in the European Union and Britain, Plymouth: Rowman and Littlefield.

Bache, I. and Jordan, A. (2006) The Europeanization of British Politics, (eds.), Basingstoke: Palgrave Macmillan.

Dunia, F. G. (1999) Harmonizing Europe: Nation-states within the Common Market, New York: State University of New York Press.

Milward, A. (1992) The European Rescue of the Nation-State, University of California Press.

Miskimmon, A. (2007) Germany and EU Foreign Policy: Between Europeanization and National Adaptation, Basingstoke: Palgrave Macmillan.

Waltz, K. (1979), Theory of International Politics, McGraw Hill.

E. Gross (2009) The Europeanization of National Foreign Policy: Continuity and Change in European Crisis Management, Basingstoke: Palgrave Macmillan.

\section{Chapters}

Andonova, L. B. (2005) 'The Europeanization of Environmental Policy in Central and Eastern Europe' in Schimmelfennig, F. and Sedelmeier, U. (eds) The Europeanization of Central and Eastern Europe, NY: Cornell University Press.

Bache, I. and Jordan, A. (2006) Europeanization and Domestic Change in I. Bache and A. Jordan, The Europeanization of British Politics, NY, Palgrave Macmillan.

Börze, T. A. (2005) 'Europeanization: How the European Union Interacts with its Member States' in Bulmer, S. and Lequesne, C. (eds) The Member States of the European Union, Oxford: Oxford University Press.

Börzel, T. A. and Panke, D. (2010) 'Europeanization' in Cini, M. and Borrogán, N. P. S. ( $3^{\text {rd }}$ edn.) European Union Politics, Oxford: Oxford University Press.

Börzel, T.A. and Risse, T. (2003) 'Conceptualizing the Domestic Impact of Europe' in Featherstone, K. and Radaelli, C. (eds) The Politics of Europeanization, Oxford: Oxford University Press.

Bulmer, S. and Burch, M. (2001) 'The Europeanization of Central Government: the UK and Germany in Historical Institutionalist Perspective' in Schneider, G. and 
Aspinwall, M. (eds.) The Rules of Integration: Institutional Approaches to the Study of Europe, Manchester: Manchester University Press.

Dyson, K. and Goetz, K.H. (2003) 'Living with Europe: Power, Constraint, an Contestation' in Dyson, K. and Goetz, K. H. (eds.) Germany, Europe and the Politics of Constraints, Oxford: Oxford University Press.

Lenschow, A. (2006) 'Europeanisation of Public Policy' in J. Richardson ( $3^{\text {rd }}$ edn.) European Union: Power and Policy-making, NY, Routledge.

Quaglia, L. et al (2007) 'Europeanisation' in Cini, M. (2 ${ }^{\text {nd }}$ edn.) European Union Politics, Oxford: Oxford University Press.

Schimmelfennig, F. and Sedelmeier, U. (2005) 'Introduction: Conceptualizing the Europeanization of Central and Eastern Europe' in Schimmelfennig, F. and Sedelmeier, U. (eds) The Europeanization of Central and Eastern Europe, NY: Cornell University Press.

Vink, and Graziano, P. (2007) 'Challenges of a New Research Agenda' in Graziano, P. and Vink, M. (eds) Europeanization: New Research Agendas, Basingstoke: Palgrave Macmillan, p. 8.

Wallace, H. (2005) 'Exercising Power and Influence in the EU: the Roles of Member States' in S. Bulmer and Ch. Lequesne, The Member States of the European Union, Oxford: Oxford University Press.

\section{Journals}

Börzel, T. A. (2002) 'Member State Responses to Europeanization', Journal of Common Market Studies, 40:2.

Börzel, T. A. (2002) 'Pace Setting, Food Dragging, and Fence Sitting: Member States Responses to Europeanization', Journal of Common Market Studies, $32: 1$.

Buller, J. and Gamble, A. (2002) 'Conceptualizing Europeanization', Public Policy and Administration-Special Issue Understanding the Europeanization of Public Policy, 17: 2.

Dyson, K. and Goetz, K. (2002) Germany and Europe: Beyond Congruence, a paper presented at Germany and Europe: A Europeanised Germany? Conference British Academy.

Héritier, A. (1996) 'The Accommodation of Diversity in European Policy-Making' Journal of European Public Policy, 3:2. 
Jordan, A. et al (2003) 'Policy Innovation or 'Muddling Through'? 'New' Environmental Policy Instruments in the United Kingdom', Environmental Politics, 12:1.

Ladrech, R. (1994) 'Europeanization of Domestic Politics and Institutions: The Case of France', Journal of Common Market Studies, 32:1.

Olsen, J. P. (2002) 'The Many Faces of Europeanization', Journal of Common Market Studies, 40:5.

Saurugger, S. (2005) 'Europeanization as a Methodological Challenge: The Case of Interest Groups', Journal of Comparative Policy Analysis, 7:4.

\section{Other sources}

Bache, I. and Marshall, A. (2004) 'Europeanisation and Domestic Change: A Governance Approach to Institutional Adaptation in Britain', Queen's Papers on Europeanisation.

Bulmer, S. and Radaelli, C. (2004) 'The Europeanization of National Policy?' Queen's Papers on Europeanisation No. 1.

Burch, M. and Gomez, R. (2003) 'Europeanization and the English Regions', ESRC/UACES Series of Seminars on EBP, University of Sheffield, Department of Politics, Sheffield, UK: http://aei.pitt.edu/1725/ (accessed 26 February 2011).

Börzel, T.A. (2003) 'Shaping and Taking EU Policies: Member States Responses to Europeanization', Queen's Papers on Europeanization, No. 2,

http://www.qub.ac.uk/schools/SchoolofPoliticsInternationalStudiesandPhilosophy/F ileStore/EuropeanisationFiles/Filetoupload,38412, en.pdf (accessed 12 February 2011).

Major, C. and Pomorska, K. (2005) 'Europeanisation: Framework or Fashion?', CFSP Forum, 3:2, p.1,

http://unimaas.academia.edu/KarolinaPomorska/Papers/110624/Europeanisation framework or fashion (accessed 11 March 2011).

Howell, K. (2003) 'The Europeanization of British Financial Services', ESRC/UACES Series of Seminars on EBP, University of Sheffield, Department of Politics, Sheffield, UK: http://aei.pitt.edu/1721/, (accessed 11 March 2011).

Goetz, K. H. and Meyer-Sahling, J. H. (2008) 'The Europeanisation of National Political Systems: Parliaments and Executives', Living Reviews in European Governance 3:2, 
http://www.livingreviews.org/lreg-2008-2 (accessed 7 March 2011).

James, S. (2007) 'Europeanisation as 'Projection': Understanding the Changing Face of EU Policy Making within the Core Executive European Policy Research Unit (EPRU)',

Political Perspectives EPRU 2007, 2: 3, http://www.politicalperspectives.org.uk/wp-content/uploads/2010/08/EPRU2007-S1-03.pdf (accessed 7 March 2011).

George, S. (2001) The Europeanization of UK Politics and Policy-Making: The Effects of European Integration on the UK. UACES/ESRC Workshop Sheffield University.

Radaelli, C. M. (2004) 'Europeanisation: Solution or Problem?', European Integration online Papers (EIoP), 8:16, http://eiop.or.at/eiop/texte/2004016a.htm (accessed 5 March 2009).

Radaelli, C. M. (2004), 'Europeanisation: Solution or Problem?', European Integration online Papers (EIoP), 8:16, available: http://eiop.or.at/eiop/texte/2004-016a.htm (accessed 5 March 2009).

Gamble, A. (2001) Europeanisation: A Political Economy Perspective, the Europeanization of British public and social policies, PAC/JUC residential school, York.

George, S. (2001) 'The Europeanization of UK Politics and Policy-Making: the Effect of European Integration in the UK', Queen's Papers on Europeanisation, No 8/2001, Belfast: Queen's University Belfast: http://www.qub.ac.uk/pais/Research/PapersSeries/, (accessed 25 February 2011).

Zatezalo, M. (2007) 'The Dual Nature of Europeanization: Divergent National Mechanisms to Common Monetary and Securities Markets Policy', http://essay.utwente.nl/58085/1/scriptie_Zatazalo.pdf. 
